\title{
Bacillus alcalophilus subsp. halodurans subsp. nov.: an Alkaline-Amylase-Producing, Alkalophilic Organism
}

\author{
E. W. BOYER, M. B. INGLE, and G. D. MERCER
}

Microbiological Research, Marschall Division, Miles Laboratories, Inc., Elkhart, Indiana 46514

\begin{abstract}
An alkaline-amylase-producing, alkalophilic bacillus, NRRL B-3881, was characterized and compared with Bacillus sp. ATCC 21591 and Bacillus alcalophilus Vedder strain NCTC 4553 (=ATCC 27647), which is here designated as the type strain of $B$. alcalophilus. All three strains contained motile, gram-positive rods with rounded ends and swollen, clavate sporangia with oval, terminal to subterminal endospores. All three strains grew in soybean broth; were facultatively anaerobic; hydrolyzed starch, gelatin, and casein; reduced methylene blue; and fermented the following carbohydrates without gas production: sucrose, D-glucose, lactose, maltose, D-mannitol, D-xylose, Larabinose, glycerol, sorbitol, and salicin. None produced acetylmethylcarbinol, indole, urease, or crystalline dextrins. Bacillus sp. ATCC 21591 and Bacillus sp. NRRL B-388 I, but not NCTC 4553, reduced nitrate to nitrite, utilized citrate, and grew well in $12 \% \mathrm{NaCl}$ and slowly in $15 \% \mathrm{NaCl}$. B. alcalophilus NCTC 4553 did not grow in $5 \% \mathrm{NaCl}$. In our opinion, these differences are sufficient to justify the establishment of a separate subspecies for ATCC 21591, NRRL B-3881, and similar strains. We propose the name $B$. alcalophilus subsp. halodurans as the name for this new subspecies. The name of the type subspecies, which contains the type strain, NCTC 4553 , is $B$. alcalophilus subsp. alcalophilus Vedder. NRRL B-3881 is designated as the type strain of $B$. alcalophilus subsp. halodurans and is available from the Northern Regional Research Laboratory. It has also been deposited in the American Type Culture Collection under the number 27557.
\end{abstract}

There have been several papers in the past few years describing alkalophilic Bacillus species that produce extracellular alkaline protease (4), amylases $(1,5,12)$, and pectinase (6). Also, alkaline-amylase-producing, alkalophilic bacilli have been described in a patent (Rikagaku Kenkyusho, Netherlands Pat. Appl. 70-13,396, 1970), as have alkaline-protease-producing, alkalophilic bacilli (K. Aunstrup et al., Great Britain Patent 1,243,784, 1971). Bacillus alcalophilus Vedder 1934 (11) produces an alkaline protease (K. Aunstrup et al., Great Britain Patent $1,205,403$, 1970). The taxonomic positions of these alkalophilic bacilli that produce extracellular alkaline enzymes have not been ascertained.

Vedder (11) isolated 16 strains of Bacillus alcalophilus fiom human feces. He deposited one strain of $\dot{B}$. alcalophilus with the National Collection of Type Cultures, London, under the number 4553. In 1956, the same strain was deposited with the National Collection of Industrial Bacteria, Edinburgh, under the number 8772, where the strain is erroneously labeled Bacillus subtilis (K. Aunstrup et al., Great Britain Patent $1,205,403,1970)$. This species grew only above $\mathrm{pH} 7$, the $\mathrm{pH}$ range for optimal growth being 8.6 to 10 . B. alcalophilus was listed in an appendix in the 6 th edition of Bergey's Manual of Determinative Bacteriology (8), but it was not mentioned in the 7 th edition (9); it was also listed in Index Bergeyana (2). In this paper, $B$. alcalophilus Vedder strain NCTC 4553 is compared with two other alkalineamylase-producing, alkalophilic bacilli, namely, Bacillus sp. NRRL B-3881 (1) and Bacillus sp. ATCC 21591 (Rikagaku Kenkyusho, Netherlands Pat. Appl. 70-13,396, 1970).

This paper was presented in part at the $72 \mathrm{nd}$ Annual Meeting of the American Society for Microbiology, Philadelphia, Pa., 23 to 28 April 1972. 


\section{MATERIALS AND METHODS}

Bacterial strains. Bacillus sp. NRRL B-3881 (Northern Regional Research Laboratory, Peoria, Ill.) was isolated from dried sewage sludge by Boyer and Ingle (1); it has been deposited in the American Type Culture Collection, Rockville, Md., under the number 27557. B. alcalophilus Vedder strain NCTC 4553 (=ATCC 27647) was obtained from the National Collection of Type Cultures, London. Bacillus sp. ATCC 21591 was obtained from the American Type Culture Collection.

Media and methods. The media and tests used were described previously by Smith et al. (10), except that it was necessary to adjust the $\mathrm{pH}$ to the range required by these alkalophilic bacteria. A $10 \%$ solution of either $\mathrm{NaHCO}_{3}$ or $\mathrm{Na}_{4} \mathrm{P}_{2} \mathrm{O}_{7} \cdot 10 \mathrm{H}_{2} \mathrm{O}$ was sterilized by autoclaving, and the amount necessary to provide a final alkali concentration of $1 \%$ was aseptically added to the test media. The $\mathrm{pH}$ values of the test media were 9.8 with $\mathrm{NaHCO}_{3}$ or 8.8 with $\mathrm{Na}_{4} \mathrm{P}_{2} \mathrm{O}_{7} \cdot 10 \mathrm{H}_{2} \mathrm{O}$. Sodium pyrophosphate buffer was substituted for sodium bicarbonate buffer in the casein and gelatin agar plates because when plates buffered with sodium bicarbonate were flooded with acid $\mathrm{HgCl}_{2}$ precipitant, bubbles formed on the agar and masked the protease hydrolysis zones.

All tests were incubated at $37 \mathrm{C}$ instead of $28 \mathrm{C}$ except where noted otherwise. In the carbohydrate fermentation tests, ammonium phosphate was the nitrogen source, and the change in $\mathrm{pH}$ was measured with a glass electrode.

It was necessary to use baffled shake flasks (Bellco, no. 599) with pad closures to obtain sporulation in the alkaline amylase production medium described by Boyer and Ingle (1). The minimal medium used to ascertain the nutritional requirements was described by Ingle and Boyer (7).

Motile cells of strains ATCC 21591 and NCTC 4553 were obtained when grown in a medium containing $0.5 \%$ tryptone (Difco), $0.5 \%$ yeast extract (Difco), $0.1 \% \mathrm{~K}_{2} \mathrm{HPO}_{4}, 0.7098 \% \mathrm{Na}_{2} \mathrm{HPO}_{4}$, and $1 \% \mathrm{NaHCO}_{3}$ (TY medium) in unbaffled shake flasks. Motile cells of NRRL B-3881 were obtained when grown in a medium containing nutrient broth (Difco), $1 \%$ $\mathrm{NaHCO}_{3}$, and $0.1 \mathrm{mM} \mathrm{MgCl}$ (NB medium) in unshaken culture tubes (R. L. Gherna, personal communication).

The effect on the growth of NRRL B-3881 of adding $5 \% \mathrm{NaCl}$ to a medium at an acid $\mathrm{pH}$ was determined by inoculating $(1 \% \mathrm{vol} / \mathrm{vol}) 50 \mathrm{ml}$ of test medium in 250-ml triple baffled shake flasks (Bellco, no. 599) with pad closures. A gyratory cabinet shaker (1-inch circular orbit; $300 \mathrm{rpm}$ ) was used at $39 \mathrm{C}$ for $18 \mathrm{~h}$.

\section{RESULTS}

All three strains studied here contained gram-positive rods with rounded ends; the sporangia were swollen and clavate, and the spores were oval and terminal to subterminal (Fig. 1). All three strains were motile. When suspensions of motile cells were stained according to I,eifson's method, Bacillus sp. ATCC 21591 (Fig. 2), B. alcalophilus NCTC 4553 (Fig. 3), and Bacillus sp. NRRL B-3881 (Fig. 4) were found to be peritrichously flagellated.

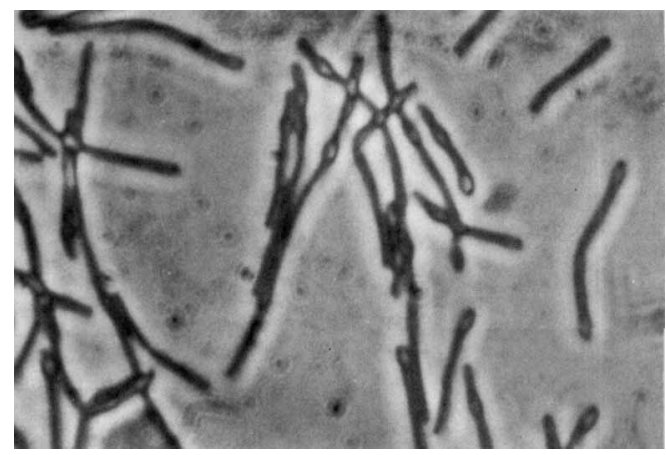

FIG. 1. Sporulated cells of Bacillus alcalophilus subsp. halodurans NRRL B-3881. Gram-stain. X1,200. Phase contrast.

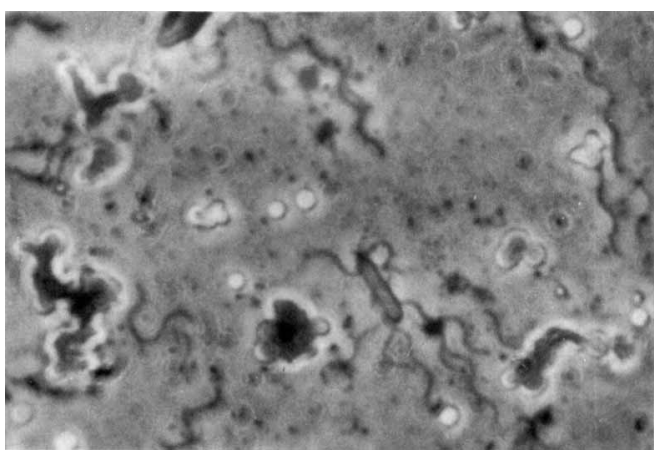

FIG. 2. Peritrichous cells of Bacillus alcalophilus subsp. halodurans ATCC 21591 from a 24-h-old $T Y$ broth culture incubated at $37 \mathrm{C}$. Stained by Leifson's method. $\times 1,200$. Phase contrast.

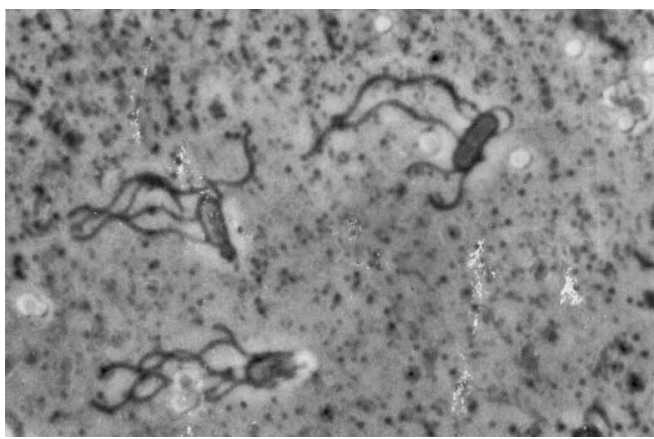

FIG. 3. Peritrichous cells of Bac.llus alcalophilus NCTC 4553 from a 24-h-old TY broth culture incubated at 37 C. Stained by Leifson's method. $\times 1,200$. Phase contrast. 
None of the strains produced acetylmethylcarbinol, indole, urease, or crystalline dextrins. All three strains grew in soybean broth; were aerobic and facultatively anaerobic; hydrolyzed starch, gelatin, and casein; reduced methylene blue; and fermented (without gas production) sucrose, D-glucose, lactose, maltose, D-mannitol, D-xylose, L-arabinose, glycerol, sorbitol, and salicin.

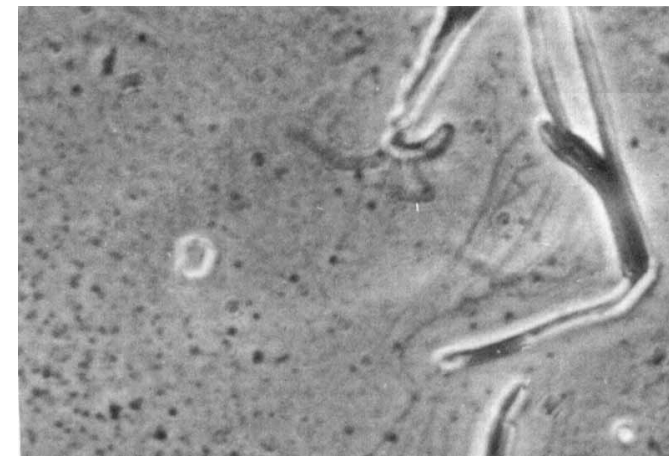

FIG. 4. Peritrichous cells of Bacillus alcalophilus subsp. halodurans NRRL B-3881 from a 24-h-old NB culture incubated at $37 \mathrm{C}$. Stained by Leifson's method. $\times 1,200$. Phase contrast.
NRRL B-3881 and ATCC 21591 grew only as pinpoint colonies, and NCTC 4553 did not grow when inoculated on plate count agar (Difco) incubated for $48 \mathrm{~h}$ at $37 \mathrm{C}$. However, the colony morphology of all three strains was similar on plate count agar containing $1 \%$ $\mathrm{NaHCO}_{3}$. After incubation for $48 \mathrm{~h}$ at $37 \mathrm{C}$, the colony diameters were 1 to $1.5 \mathrm{~mm}$ (NCTC 4553), $2.3 \mathrm{~mm}$ (NRRL B-3881), and $1.5 \mathrm{~mm}$ (ATCC 21591). The colonies were white, smooth, shiny, and convex with entire margins.

ATCC 21591 and NRRL B-3881 utilized citrate, reduced nitrate to nitrite, grew well in $12 \% \mathrm{NaCl}$, and grew slowly in $15 \% \mathrm{NaCl}$. NRRL B-3881 tolerated 9, 12, and 15\% $\mathrm{NaCl}$ better than did ATCC 21591 (Table 1). B. alcalophilus did not grow in $5 \% \mathrm{NaCl}$. Only ATCC 21591 formed a pellicle on broth.

The differences between the three strains studied are summarized in Table 1.

A description of NRRL B-3881, designated below as the type strain of a new subspecies, follows. Vegetative cells are gram-positive, encapsulated, straight rods $(0.9$ to $1 \mu \mathrm{m}$ by 3 to $4 \mu \mathrm{m}$ ) with rounded ends, occurring in small chains of two to six cells (Fig. 1). Chains were not produced in the growth on soybean agar. The cells were small, twisted, and bent when

TABLE 1. Differentiation of NRRL B-3881, ATCC 21591, and NCTC $4553^{a}$

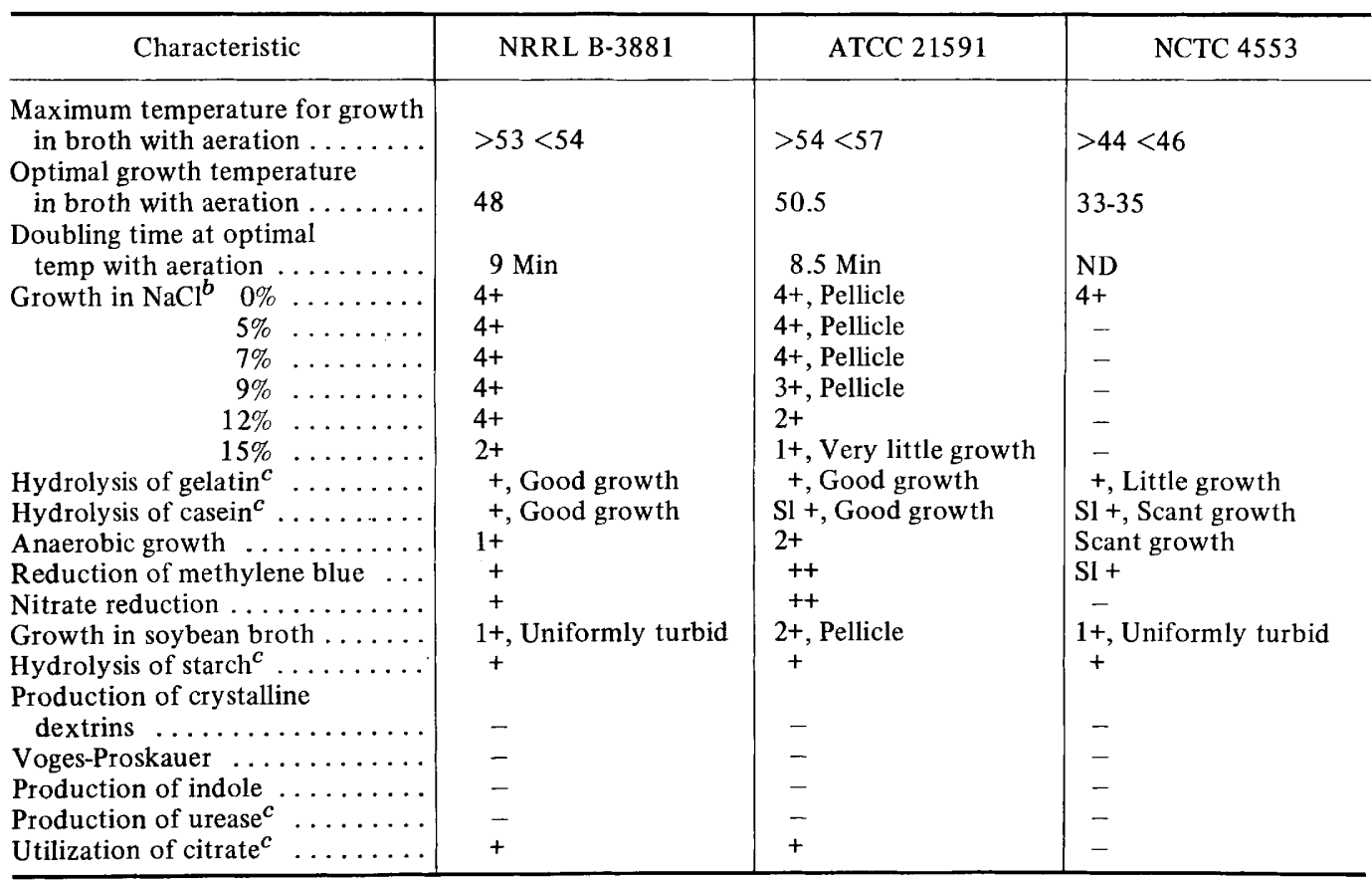

${ }^{a}$ Symbols: ND, not done; $\mathrm{Sl}+$, slight reaction; +, positive; ++ , more positive; - , negative.

$b$ Grown without shaking for $48 \mathrm{~h}$ at $37 \mathrm{C}$, pH 9.8 .

c $1 \% \mathrm{Na}_{4} \mathrm{P}_{2} \mathrm{O}_{7} \cdot 10 \mathrm{H}_{2} \mathrm{O}$ buffer (pH 8.8) instead of $1 \% \mathrm{NaHCO}_{3}$ buffer (pH 9.8) was used. 
grown in media with no added $\mathrm{NaCl}$ at $\mathrm{pH} 7$ to 8. The sporangia were swollen and clavate (Fig. 1). The spores were oval $(0.5$ to $0.8 \mu \mathrm{m}$ by 1 to $1.5 \mu \mathrm{m})$, terminal to subterminal, and refractile (Fig. 1). Sporulation in the alkaline-amylase production medium at $37 \mathrm{C}$ began at $12 \mathrm{~h}$ and was nearly complete after $48 \mathrm{~h}$. The maximum temperature for growth in broth with aeration was between 53 and $54 \mathrm{C}$; the optimal temperature with aeration was $48 \mathrm{C}$. Without aeration, slow growth occurred at $26 \mathrm{C}$; a higher growth rate was obtained at temperatures above $40 \mathrm{C}$ than at those below $33 \mathrm{C}$. Slow growth resulting in small colonies was obtained on TYG agar at $\mathrm{pH} 7.0$; in nutrient broth (Difco) at pH 9, the growth was flocculent with a slimy sediment; there was growth but no sporulation on alkaline nutrient agar (Difco) slants and on alkaline soybean agar slants. The initial $\mathrm{pH}$ of glucose broth was 10 , and the final $\mathrm{pH}$ was 8.98 after $18 \mathrm{~h}$ at $37 \mathrm{C}$. Growth was produced in a basal salts medium containing sodium citrate, magnesium sulfate, sodium phosphate, calcium chloride, sodium sesquicarbonate, ammonium sulfate, and carbohydrate at $\mathrm{pH} 9.3(10)$. The addition of $5 \%$ $\mathrm{NaCl}$ to the basal medium at pH 6.6 resulted in growth, as measured by the change in optical density at $525 \mathrm{~nm}\left(\Delta O D_{525}\right)$, equal to that obtained with a medium at $\mathrm{pH} 8.8$ with no $\mathrm{NaCl}$ added (Table 2).

\section{DISCUSSION}

NRRL B-3881 is similar to ATCC 21591, but both are different from $B$. alcalophilus NCTC 4553. Both reduced nitrate to nitrite, utilized citrate, and grew well in $12 \% \mathrm{NaCl}$ and slowly in $15 \% \mathrm{NaCl}$. However, B. alcalophilus NCTC 4553 did not utilize citrate, reduce nitrate to nitrite, or grow in $5 \% \mathrm{NaCl}$. There were some qualitative differences between NRRL B-3881 and ATCC 21591. However, in the genus Bacillus variations in characters frequently occur among strains within a species (9).

TABLE 2. Effect of $\mathrm{NaCl}$ and $\mathrm{pH}$ on B. alcalophilus subsp. halodurans NRRL B-3881

\begin{tabular}{l|c|c|c}
\hline \multicolumn{1}{c|}{ Medium } & Initial pH & Final pH & $\Delta \mathrm{OD}_{525}$ \\
\hline Basal $^{a}$ & 6.59 & 6.59 & 0 \\
Alkaline basal $^{b}$ & 8.79 & 8.54 & 0.36 \\
Basal $+5 \% \mathrm{NaCl}$ & 6.59 & 6.86 & 0.36 \\
\hline
\end{tabular}

${ }^{a}$ Basal medium: $0.1 \%\left(\mathrm{NH}_{4}\right)_{2} \mathrm{HPO}_{4}, 0.02 \% \mathrm{KCl}$, $0.02 \% \mathrm{MgSO}_{4}, 0.02 \%$ yeast extract (Difco), and $1 \%$ lactose; pH 6.59.

${ }^{b}$ Alkaline basal medium: basal medium plus $1 \%$ $\mathrm{Na}_{4} \mathrm{P}_{2} \mathrm{O}_{7} \cdot 10 \mathrm{H}_{2} \mathrm{O}, \mathrm{pH} 8.79$.
ATCC 21591 and NRRL B-3881 can therefore be differentiated from $B$. alcalophilus on the basis of citrate utilization, nitrate reduction, and growth in salt solutions. In our opinion these differences are sufficient to justify the classification of NRRL B-3881 and ATCC 21591 in a new subspecies, for which we propose the name Bacillus alcalophilus subsp. halodurans (Gr. noun hals, halis salt; L. part. adj. durans hardening, resisting; M.L. part. adj. halodurans salt-resisting). NRRL B-3881 is designated as the type strain; a description of this strain is given above.

A composite description of $B$. alcalophilus subsp. halodurans subsp. nov. follows (the $\mathrm{pH}$ of the medium must be alkaline [preferably between $\mathrm{pH} 8$ and 10] for normal growth and morphology; however, there is some growth at pH 7): gram-positive (rarely gram-variable), straight, motile rods with rounded ends and peritrichous flagella; sporangia are swollen and clavate; spores are oval, terminal and subterminal, and refractile; acetylmethylcarbinol, indole, urease, and crystalline dextrins are not produced; growth occurs in soybean broth; aerobic, facultatively anaerobic; starch, gelatin, and casein are hydrolyzed; methylene blue is reduced; sucrose, D-glucose, lactose, maltose, D-mannitol, D-xylose, L-arabinose, glycerol, sorbitol, and salicin are fermented without gas production; citrate is utilized; nitrate reduced to nitrite; good growth in $7 \%$ (one strain in $12 \%$ ) $\mathrm{NaCl}$; slow growth in $15 \% \mathrm{NaCl}$; maximum temperature for growth in broth with aeration, 53 to $55 \mathrm{C}$; optimal growth temperature in broth with aeration, 48 to $50 \mathrm{C}$; slow growth in broth without aeration at $26 \mathrm{C}$; colonies grown on plate count agar (Difco) containing $1 \% \mathrm{NaHCO}_{3}$ at $37 \mathrm{C}$ for $48 \mathrm{~h}$ are white, smooth, shiny, and convex with entire margins.

A comparison of the characters reported here for B. alcalophilus NCTC 4553, one of Vedder's strains, with those originally described for 16 strains of $B$. alcalophilus by Vedder (11) shows that NCTC 4553 still has the characters of $B$. alcalophilus as originally described by Vedder. To our knowledge, a type strain has not previously been designated for B. alcalophilus; therefore, NCTC 4553 (=ATCC 27647) is here designated as the type strain of this species.

$B$. alcalophilus belongs to group II (9) of the genus Bacillus. Morphologically and physiologically it is related most closely to Bacillus circulans. However, it is not closely related to the strain of $B$. circulans described by Chislett and Kushner (3), which is capable of growing under highly alkaline conditions.

It is worthy of note that NRRL B-3881, the 
type strain of $B$. alcalophilus subsp. halodurans, ordinarily does not grow in media below $\mathrm{nH}$ 7.0. However, if $5 \% \mathrm{NaCl}$ is added to a medium at $\mathrm{pH} 6.6$, it grows as well as it does in a medium at $\mathrm{pH} 8.8$ without $\mathrm{NaCl}$ added. We cannot explain how the presence of $5 \% \mathrm{NaCl}$ enables NRRL B-3881 to grow at $\mathrm{pH}$ 6.6. Further study on this phenomenon is warranted.

\section{ACKNOWLEDGMENT}

The technical assistance of Donald D. Stante is gratefully acknowledged.

\section{REPRINT REQUESTS}

Address requests for reprints to: Ernest W. Boyer, Microbiological Research, Marschall Division, Miles Laboratories, Inc., Elkhart, Ind. 46514.

\section{LITERATURE CITED}

1. Boyer, E. W., and M. B. Ingle. 1972. Extracellular alkaline amylase from a Bacillus species. J. Bacteriol. 110:992-1000.

2. Buchanan, R. E., J. G. Holt, and E. F. Lessel, Jr. 1966. Index Bergeyana, The Williams \& Wilkins Co., Baltimore.

3. Chislett, M. E., and D. J. Kushner. 1961. A strain of Bacilius circulans capable of growing under highly alkaline conditions. J. Gen. Microbiol. 24:187-190.
4. Horikoshi, K. 1971. Production of alkaline enzymes by alkalophilic microorganisms. Part I. Alkaline protease produced by Bacillus no. 221. Agr. Biol. Chem. 35:1407-1414.

5. Horikoshi, K. 1971. Production of alkaline enzymes by alkalophilic microorganisms. Part II. Alkaline amylase produced by Bacillus no. A-402. Agr. Biol. Chem. 35:1783-1791.

6. Horikoshi, K. 1972. Production of alkaline enzymes by alkalophilic microorganisms. III. Alkaline pectinase of Bacillus no. P-4-N. Agr. Biol. Chem. 36:285-293.

7. Ingle, M. B., and E. W. Boyer. 1972. Alkaline amylase synthesis by a Bacillus species. Develop. Ind. Microbiol. 13:421-427.

8. Smith, N. R. 1948. Genus I. Bacillus Cohn, p. 705-762. In R. S. Breed, E. G. D. Murray, and A. P. Hitchens (ed.), Bergey's manual of determinative bacteriology, 6th ed. The Williams \& Wilkins Co., Baltimore.

9. Smith, N. R., and R. E. Gordon. 1957. Genus I. Bacillus Cohn, p. 613-634. In R. S. Breed, E. G. D. Murray, and N. R. Smith (ed.), Bergey's manual of determinative bacteriology, 7 th ed. The Williams \& Wilkins Co., Baltimore.

10. Smith, N. R., R. E. Gordon, and F. E. Clark. 1952. Aerobic sporeforming bacteria. U.S. Dept. Agr. Monogr. no. 16. Washington, D.C.

11. Vedder, A. 1934. Bacillus alcalophilus n. sp.; benevens enkle ervaringen met sterk alcalische voedingsbodems. Antonie van Leeuwenhoek J. Microbiol. Serol. 1:141-147.

12. Yamamoto, M., Y. Tanaka, and K. Horikoshi. 1972. Alkaline amylases of alkalophilic bacteria. Agr. Biol. Chem. 36:1819-1823. 